SJ Quinney College of Law, University of Utah

Utah Law Digital Commons

$8-2020$

Indian Country Post McGirt: Implications for Traditional Energy

Development and Beyond

Elizabeth Kronk Warner

Heather Tanana

Follow this and additional works at: https://dc.law.utah.edu/scholarship

Part of the Indian and Aboriginal Law Commons, and the Natural Resources Law Commons 


\title{
INDIAN COUNTRY POST-MCGIRT: IMPLICATIONS FOR TRADITIONAL ENERGY DEVELOPMENT AND BEYOND
}

\author{
Elizabeth Kronk Warner1 and Heather Tanana2
}

\begin{abstract}
The decision in McGirt v. Oklahoma is being heralded as the most important Indian law decision of the last 100 years, as it affirmed the reservation boundaries of the Muscogee (Creek) Reservation - an area long considered by many to be under Oklahoma's jurisdiction. Yet, following release of the Court's decision, the outcry from the oil and gas industry was almost instantaneous, as roughly twenty five percent of Oklahoma's oil and gas well and sixty percent of its oil refineries are impacted by the Court's decision. Additionally, the territory affected by the Court's decision also includes pipelines crucial to the successful operation of the nationwide Keystone XL pipeline. While the Court was clear that its holding was limited to criminal jurisdiction under the Major Crimes Act, the decision nonetheless has broader implications for Indian country, including natural resource development and regulatory framework. Because the oil and gas industry will now have to work with tribes and the federal government instead of favorable state officials, industry officials decry the Court's decision as being detrimental to the industry. But what exactly will be the impact of the Court's McGirt decision on the oil and gas industry, and the natural resources development in Indian country more broadly? While the full impacts of the Court's decision are only beginning to unfold, this Article seeks to answer the questions left hanging by the Court's decision as they relate to traditional energy development. This Article explores the future impacts of the McGirt decision on traditional energy development. The second Part of the article summarizes the legal background that governs oil and gas development in Indian country. Part three provides an in-depth analysis of McGirtfirst, describing its predecessor, Sharp v. Murphy, followed by an explanation of McGirt and its holding. The article concludes by discussing future implications of McGirt, including what it means for oil and gas development going forward as well as collateral effects. The article constitutes an important scholarly contribution as it answers important questions left open after the Court's decision and explains how the Court's decision has broader implications for Indian country and natural resource development generally.
\end{abstract}

\section{Table of Contents}

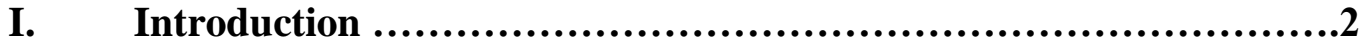

II. Resource Development in Indian Country ...........................3

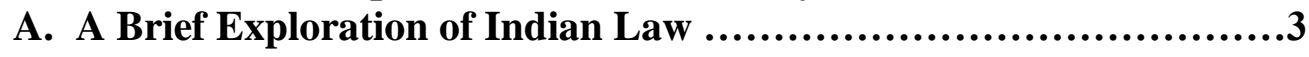

B. Oil and Gas Leasing in Indian Country .............................4

III. Sharp v. Murphy, McGirt v. Oklahoma, and the Emerging Epilogue:

A Three-Part Saga ...............................................6

1 Elizabeth Kronk Warner is the Jefferson and Rita Fordham Presidential Dean and Professor of Law at the S.J. Quinney College of Law. She is also a citizen of the Sault Ste. Marie Tribe of Chippewa Indians.

2 Heather Tanana is a Research Professor at the S.J. Quinney College of Law, and she is a citizen of the Navajo Nation. 


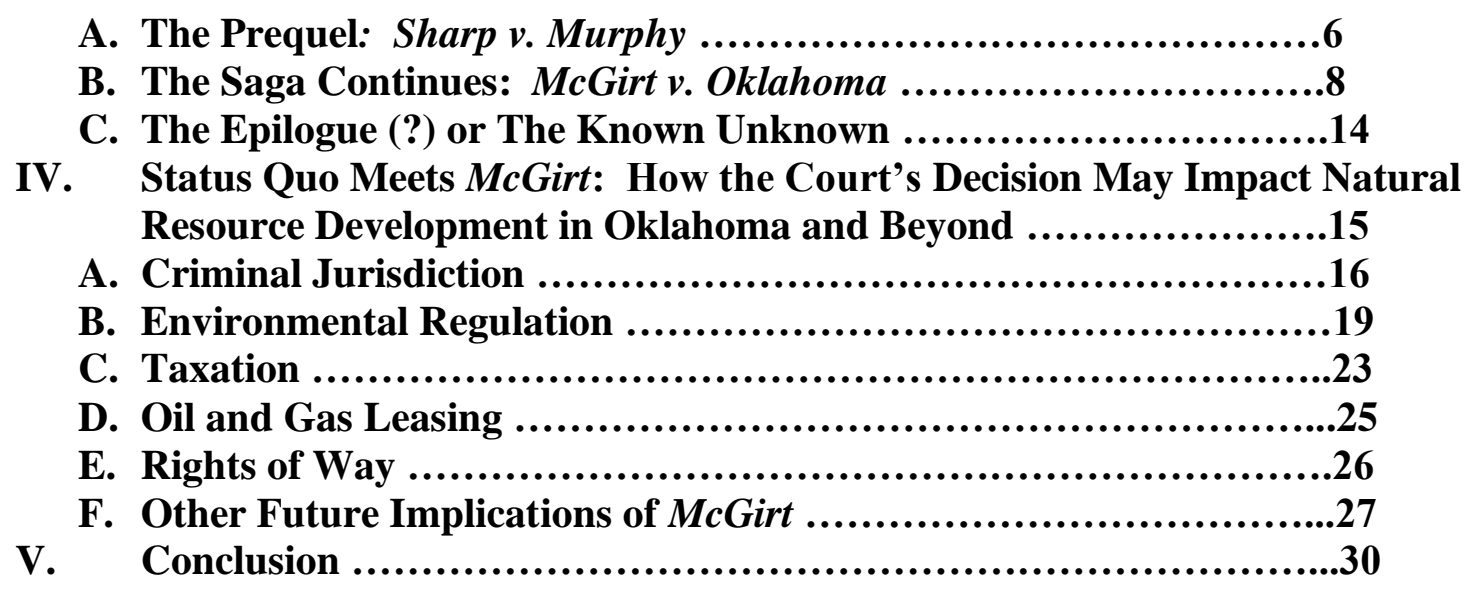

\section{Introduction}

The decision in McGirt v. Oklahoma 3 is being heralded as the most important Indian law decision in the past 50 years, if not the century. In McGirt, the U.S. Supreme Court upheld a Tribal nation's treaty rights in determining that a portion of Oklahoma remained part of the Muskogee Creek reservation. While the Court was clear that its holding was limited to criminal jurisdiction under the Major Crimes Act, the decision nonetheless has broader implications for Indian country, including natural resource development and regulatory framework.

Indian country includes approximately 56.2 million acres of trust lands 4 and holds an abundance of mineral and energy resources. American Indian Tribes are the third-largest owners of mineral resources in the United States.5 Tribal lands contain approximately three to four percent of known oil and gas reserves, about thirty percent of western coal reserves, and a third or more of uranium deposits. 6 More than ten percent of federal on-shore energy production occurs on Indian lands.7 And, with approximately 15 million acres of energy resources yet to be developed, 8 Indian country can continue to help meet the energy demands of Americans into the foreseeable future.

However, Tribal communities have not always benefited from conventional energy development. While in theory oil and gas royalty revenues should strengthen tribal economies, in the past, Tribes have received below market rates.9 Fossil fuel production enterprises have also been connected to increased violence against Native women 10 and environmental degradation. Indeed, Tribes continue to face negative health implications from uranium mines long closed.11

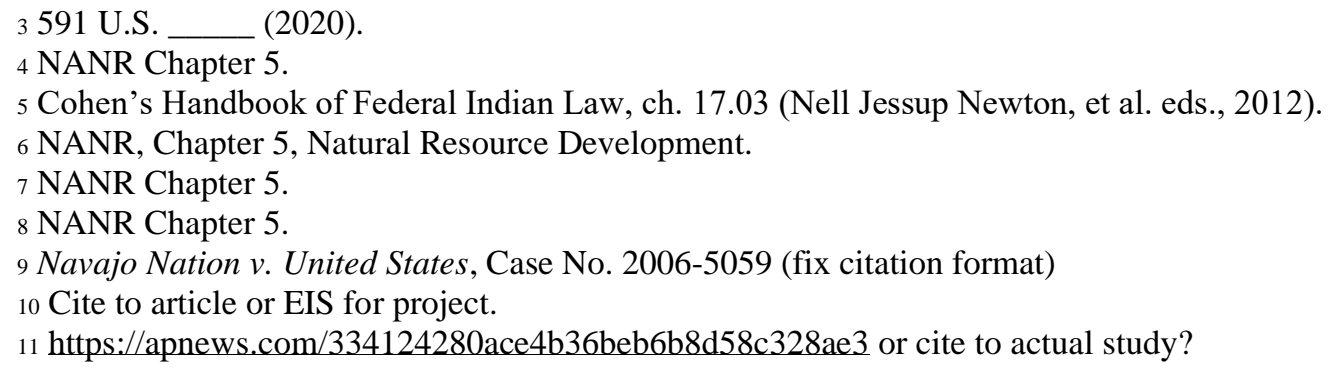


Nonetheless, the McGirt decision reinforces Tribal sovereignty and the ability of Tribes to not only direct their own future, but to hold other actors accountable as well. Given the extensive resources contained within Indian country, the McGirt decision has the potential to further position American Indian Tribes as key players in energy development in the 21 st century.

This Article explores the future impacts of the McGirt decision on traditional energy development. The second Part of the article summarizes the legal background that governs oil and gas development in Indian country. Part three provides an in-depth analysis of McGirtfirst, describing its predecessor, Sharp v. Murphy, followed by an explanation of McGirt and its holding. The article concludes by discussing future implications of McGirt, including what it means for oil and gas development going forward as well as collateral effects.

\section{Resource Development in Indian Country}

Natural resource development in Indian country occurs within the confines of Indian law. In order to understand the potential implications of McGirt, this Part sets the stage by providing an introduction to applicable Indian law principles and the regulatory framework in Indian country.

\section{A. A Brief Exploration of Indian Law}

Tribal sovereignty is at the heart of Indian law. Simply stated, Tribal sovereignty is the inherent ability of Tribes to govern their members and territory. It "provides a backdrop against which the applicable treaties and federal statutes must be read." 12 As sovereign nations, Tribes interact with the federal government and states on a government-to-government basis. However, Tribal sovereignty is not absolute. In a series of cases called the Marshall trilogy, the U.S. Supreme Court set forth the basis for Tribal sovereignty, while also limiting its reach. The Court coined Tribes as "domestic dependent nations." 13 "They are denominated domestic because they are within the United States and dependent because they are subject to federal power." 14 The result is the creation of a trust relationship between Tribes and the United States. "This relation [is] that of a nation claiming and receiving the protection of one more powerful: not that of individuals abandoning their national character, and submitting as subjects to the laws of a master."15 Under the trust doctrine, the United States has a duty to act in good faith in its dealings with Tribes, much like that of a trustee and beneficiary. 16

Jurisdiction in Indian country is a fluid concept that has continued to evolve since the Marshall trilogy. In order to determine who has proper jurisdiction - the Tribe, state or federal government - basic facts must be gathered regarding who is involved and where the event took place. As an initial matter, Tribes generally cannot act outside of Indian country. Indian country is statutorily defined as (a) all land within the limits of any Indian reservation; (b) all dependent Indian communities; and (c) all Indian allotments.17 Reservations may be established by treaty,

12 McClanahan v. State Tax Comm'n of Ariz., 411 U.S. 164, 172 (1973).

${ }_{13}$ Cherokee Nation v. Georgia, 30 U.S. 1, 17 (1831).

${ }_{14}$ Cohen's Handbook of Federal Indian Law, ch. 1 (Nell Jessup Newton, et al. eds., 2012).

15 Worcester v. George, 31 U.S. 515, 555 (1832).

${ }_{16}$ Cherokee Nation v. Georgia, 30 U.S. 1, 17 (1831) (describing the Tribal-federal relationship as resembling "a ward to his guardian").

1718 U.S.C. $\$ 1151$ (2006). 
statute, executive order, or administrative proclamation. To qualify as a dependent Indian community, the land must satisfy two requirements: (1) have been set aside by the federal government "for the use of the Indians as Indian land," and (2) be under federal superintendence. 18 Finally, Indian allotments are the result of the allotment era, during which the federal government allotted lands - in trust or in fee - to individual Tribal members. The Indian country footprint has changed over time, with reservation boundaries being the subject of extensive litigation. 19 However, determining the geographic boundaries of a reservation can be critical to determining proper jurisdiction.

Tribes retained inherent authority to exercise civil and regulatory control over non-Indians in Indian country. However, Tribal authority over non-Indians on non-Indian fee land located within a reservation is limited. The U.S. Supreme Court set forth the conditions required to exercise such civil jurisdiction in Montana $v$. United States. First, Tribes "may regulate through taxation, licensing, or other means the activities of nonmembers who enter into consensual relationships with the tribe or its members, through commercial dealing, contracts, leases, or other arrangements." 20 Second, a tribe may "exercise civil authority over the conduct of nonmembers on fee lands within its reservation when that conduct threatens or has some direct effect on the political integrity, the economic security, or the health and welfare of the tribe." 21 The extent of Tribal jurisdiction over non-Indians has been shaped by caselaw22 and continues to be tested to this day.

\section{B. Oil \& Gas leasing in Indian Country}

Many Tribes rely on natural resource development as a means of economic development. "In 2019, federal recognized Indian tribes . . . and individual Indian mineral owners received \$1.1 billion in energy and mineral revenue - the largest source of revenue generated from natural resources on trust lands." 23 In Indian country, resource development can occur in three ways: (1) Tribes may develop their resources directly; (2) Tribes may assume administration of a federal Indian program through contracts and self-governance compacts;24 and (3) non-Tribal entities may enter into leases or other arrangements to develop the land.25 Most development occurs through the third option 26 and will be discussed in more detail below.

As a practical matter, Tribal oil and gas interests are the product of treaty language and the Allotment era. Tribes have sole authority for leasing mineral rights on tribal lands owned in fee.

18 Native Vill. of Venetie Trib. Gov't, 522 U.S at 520.

19 See e.g., Ute Indian Tribe v. Utah, 114 F.3d 1513 (10th Cir. 1997).

20 Montana, 450 U.S. at 565.

21 Montana, 450 U.S. at 565.

22 See e.g., Atkinson Trading Co. Inc. v. Shirley, 532 U.S. 645, 647 (2001), Strate v. Al Contractors, 520 U.S. 438 (1997).

23 Congressional Research Service, Tribal Energy Resource Agreements (TERAs): Approval Process and Selected Issues for Congress (July 9, 2020), https://fas.org/sgp/crs/misc/R46446.pdf.

24 Indian Self-Determination and Education Assistance Act of 19784, Public Law 93-638, 88 Stat. 2203 (codified as amended in 25 U.S.C.).

25 NANR Chapter 5 or other cite?

26 NANR Chapter 5 or The Harvard Project on American Indian Economic Development, The State of Native Nations: Conditions under U.S. Policies of Self-Determination, 4 (2008). 
The Department of the Interior, through the Bureau of Indian Affairs, holds title to trust lands for Tribes. Federal approval is generally required for leases with non-Indian entities on trust lands. This requirement stems from the Nonintercourse Act, which prohibits the "purchase, grant, lease, or other conveyance" of Indian lands without federal approval.27 Failure to obtain Secretarial approval means that the subject agreements are void.28 Once the lease has been approved, the federal government continues to have a trust responsibility toward the Tribe and trust allottees. 29

Mineral rights are presumed to have passed to the Tribe when a reservation has been established, unless specifically excluded.30 In some cases, the mineral rights may be separated from the surface rights, creating a split estate. In those instances, additional challenges may arise in determining what materials are included within the mineral reservation and to what extent the surface owner must accommodate the mineral owner. The surface owner generally must accommodate the mineral owner. However, under the Accommodations Doctrine, the mineral owner must show due regard for the interests of the surface owner and only occupy those portions that are reasonably necessary to develop the mineral estate.31 Dealing with split estates in Indian Country may be particularly challenging when the surface interests contain sacred religious or cultural sites.

The Indian Mineral Leasing Act of 1938 (IMLA), Indian Mineral Development Act of 1982 (IMDA), Indian Tribal Energy Development and Self-Determination Act of 2005 (ITEDSA), and Indian Tribal Energy and Self-Determination Act Amendments of 2017 (ITEDSA 2017) govern oil and gas leasing of Indian lands. The IMLA sought to provide uniformity to leasing laws of Indian lands and to ensure Indians received the greatest return from their property.32 The IMLA allowed Indian lands to be leased for an initial term of 10 years, and then continuing thereafter subject to Tribal consent and Secretary approval.33 While leasing can be lucrative, producing lease revenues for Tribes, there have been other casualties from leasing. "Some leases may bring large numbers of non-Indians onto the reservation or may entice states to attempt to exercise regulatory and taxing powers over reservations." 34

The IMDA still sought to maximize the financial return for Tribes; but, it also sought to further tribal self-governance. 35 Subject to Secretary approval, Tribes were authorized to enter into minerals agreements, including "any joint venture, operating, production sharing, service, managerial, lease or other agreement." 36 As a result, Tribes are able to more meaningfully participate in the decision-making process and directly engage in the negotiations. Beyond

\footnotetext{
27 Add citation.

28 See 25 C.F.R. Section 211.53 (a).

29 United States v. Mason, 412 U.S. 391,398 (1973).

30 United States v. Shoshone Tribe, 304 U.S. 111 (1938).

31 The Accommodations Doctrine has been developed through caselaw and is also known the "alternative means doctrine" and "due-regard" approach.

3225 U.S.C. $§$ 396-(a)-(g); Montana v. Blackfeet Tribe, 471 U.S. 759, 767 n.5 (1985).

3325 U.S.C. § 396a (2009), 25 U.S.C. § 415 (2006).

34 Reid Peyton Chambers and Monroe E. Price, Regulating Sovereignty: Discretion and the Leasing of Indian Lands, 26 Stan. L. Rev. 1061, 1063 (1974).

3525 U.S.C. $\$ \$ 2101-2108 ;$ S. Rep. No. 97-472, 97th Cong. 2d Sess. 2 (1982).

3625 U.S.C. $\S 2102(a)$
} 
merely providing approval, upon request, the Secretary must also provide assistance to Tribes during negotiations.37

The ITEDSA further expanded Tribal control over resource development and the leasing process.38 Through Tribal Energy Resource Agreements (TERAs), Tribes may enter into leases and business agreements.39 While Secretary approval is required for TERAs, once approved, no further approval is required for the specific lease or mineral agreement that follows. The ITEDSA also includes provisions for scientific and technical assistance. Upon Tribal request, the Secretary shall ensure the Tribe has "available scientific and technical information and expertise, for use in the regulation, development, and management of energy resources of the Indian tribe on Indian land." 40 While the ITEDSA paved the way for greater Tribal control, few Tribes initiated the TERA process due to lack of capacity, uncertainty regarding the process, and concerns about the costs to Tribes. 41 Ultimately, no Tribes succeeded in entering into a TERA with the Secretary.

In December 2018, Congress enacted ITEDSA 2017 to address Tribal concerns and the following year, the Department of Interior finalized amendments to its regulations.42 ITEDSA 2017 amended the procedural requirements for TERAs, including the timeframe for processing a TERA and funding agreements. Whether the amendments and regulations were sufficient to remove barriers to development remains yet to be seen.

\section{Sharp v. Murphy, McGirt v. Oklahoma, and the Emerging Epilogue: A Three- Part Saga}

Having provided a background in the law as it currently exists in relation to oil and gas and natural resourced development in Indian country, this Part now examines the U.S. Supreme Court cases that have the potential to disrupt the present scheme - Sharp v. Murphy and McGirt v. Oklahoma. The Part presents a descriptive analysis of these cases so that the arguments made, and the Court's reasoning become clear. With the previous Part's background in place and this Part's descriptive analysis, the following Part will demonstrate how these two cases potentially might impact oil and gas and natural resource development in Oklahoma.

\section{A. The Prequel: Sharp v. Murphy}

The long and winding road leading to the U.S. Supreme Court's decision in McGirt v. Oklahoma actually begins with a previous case, Sharp v. Murphy.43 In Sharp v. Murphy, an Oklahoma prisoner was convicted of first degree murder and sentenced to death. Following his conviction, he filed a writ of habeas corpus arguing that, because the murder occurred within the Muscogee (Creek) Reservation, the state court did not have jurisdiction in the matter. The relevant question

3725 U.S.C. $\$ 2106$.

3825 U.S.C. $\$ \$ 3501-3506$.

3925 U.S.C. $\$ 3504(a)-(b)$.

4025 U.S.C. $\$ 3503$.

${ }_{41}$ Congressional Research Service, Tribal Energy Resource Agreements (TERA) at 1.

42 P.L. 115-325.

43 Sharp v. Murphy, No. 17-1107 (U.S. Jul. 9, 2020) (“The judgment of the United States Court of Appeals for the

Tenth Circuit is affirmed for the reasons stated in McGirt v. Oklahoma, ante, p. .") 
of Indian law before the Tenth Circuit was whether the Muscogee (Creek) Reservation had been diminished or disestablished. The court held that the reservation had not been disestablished, and, as a result, the federal government and not the state had jurisdiction over the crime. 44

Mr. Murphy is a citizen of the Muscogee (Creek) Nation. He was charged with murdering another man. After his conviction in state court, Mr. Murphy raised the question of the status of the land where the murder was allegedly committed. If the land in question was Indian country, then the state would not have jurisdiction over the crime, as the Major Crimes Act would apply giving the federal government jurisdiction. The court therefore focused on whether the land in question was Indian country, or, in the alternative, if the Muscogee (Creek) Nation's reservation had been disestablished and therefore the land in question was no longer Indian country.

As a starting point, the Tenth Circuit explained that the Major Crimes Act45 applies to major crimes, including murder, committed within Indian country. The Major Crimes Act makes jurisdiction over such crimes concurrent between the federal government and tribe. Jurisdiction does not depend on whether the victim is an Indian. Further, "all lands within the boundaries of a reservation have Indian country status" for purposes of the Major Crimes Act.46 Accordingly, if the murder occurred within the boundaries of the Muscogee (Creek) Reservation, then the federal government, and not the state, would have jurisdiction under the Major Crimes Act.

The Tenth Circuit next focused on determining whether or not the land where the murder occurred was within the Muscogee (Creek) Reservation. Only Congress can diminish or disestablish an Indian reservation, so, in determining the status of the land, the court focused on the actions and intent of Congress. Courts cannot lightly infer disestablishment or diminishment, and, as a result, the presumption is against diminishment or disestablishment. The court looked for clear and plain intent that Congress wanted to diminish or disestablish the Reservation. The court applied the factors from the U.S. Supreme Court's decision in Solem v. Bartlett47 to determine whether diminishment or disestablishment had occurred. Under Solem, courts examine the relevant statutory text to see if diminishment or disestablishment occurred. Explicit reference to cessation will indicate that Congress intended to diminish or disestablish the reservation. The second factor requires courts to consider events surrounding passage of the relevant congressional act. And, to a lesser extent, the third factor instructs courts to consider relevant subsequent historical treatment, such as how Congress treated the land in question and demographics of the area.48 Finally, courts must resolve any ambiguities in the favor of tribes.49

The Tenth Circuit then went on to apply the three Solem factors to the present case. The court explained that, as to the first factor, there are no "magic" words of cessation. The court provided extensive detail related to the history of the Muscogee (Creek) Nation. As to the first factor, the court concluded that " $[\mathrm{t}]$ he most important evidence - the statutory text - fails to reveal disestablishment at step one. Instead, the relevant statutes contain language affirmatively

44875 F.3d 896 (10th Cir. Nov. 9, 2017).

4518 U.S.C. $\$ 1153$.

46 Murphy, 875 F.3d at 917.

47465 U.S. 463 (1984)

48 Murphy, 875 F.3d at 920-21.

49 Id. at 921. 
recognizing the Creek Nation's borders." 50 In terms of the second and third factors, the court concludes that the evidence is "mixed" and does not clearly support or negate disestablishment or diminishment. Accordingly, since ambiguities are to be resolved in favor of tribes, the court concludes that there is no evidence to support a finding of diminishment or disestablishment.51 The Tenth Circuit ultimately held that the evidence does not support a finding that the reservation was diminished or disestablished, and, as a result, the state did not have jurisdiction over the alleged crimes committed by Mr. Murphy.

The sole question presented in the petition for writ of certiorari from the Tenth Circuit's decision was "Whether the 1866 territorial boundaries of the Creek Nation within the former Indian Territory of eastern Oklahoma constitute an "Indian reservation" today under 18 U.S.C. $\S$ 1151(a)." 52 The U.S. Supreme Court granted the petition for writ of certiorari from the Tenth Circuit's decision on May 21, 2018.53 Because Justice Gorsuch sat on the Tenth Circuit at the time of its earlier decision in the case, he took no part in the Court's decision. Following the Court's grant of certiorari, the case took a series of unique twists. On September 24, 2018, the U.S. Solicitor General filed a motion for leave to participate in oral argument as amicus curiae.54 On November 27, 2018, the Court heard oral argument in the case, but, on December 4, 2018, in an unusual development the Court requested supplemental briefing on two questions:

(1) Whether any statute grants the state of Oklahoma jurisdiction over the prosecution of crimes committed by Indians in the area within the 1866 territorial boundaries of the Creek Nation, irrespective of the area's reservation status. (2) Whether there are circumstances in which land qualifies as an Indian reservation but nonetheless does not meet the definition of Indian country as set forth in $18 \mathrm{U}$. S. C. $\S 1151(a) .55$

Supplemental briefs were filed by the parties, the United States, and the Muscogee (Creek) Nation.56 In a highly unusual twist, the Court failed to reach a decision in the case and restored the case to the Court's calendar for rehearing on June 27, 2019.57 The Court never heard rehearing in Sharp v. Murphy, as it instead accepted cert in McGirt.

\section{B. The Saga Continues: McGirt v. Oklahoma}

$50 \mathrm{Id}$. at 937.

51 Id. at 954-66.

52 Royal v. Murphy, On Petition for a Writ of Certiorari to the United States Court of Appeals for the Tenth Circuit,

No. 17- (Feb. 6, 2018), available at: https://www.supremecourt.gov/DocketPDF/17/17-

1107/34619/20180206172951133_17___PetitionForAWritOfCertiorari.pdf.

53 SCOTUSBlog, Sharp v. Murphy, available at: https://www.scotusblog.com/case-files/cases/sharp-v-murphy/ (last accessed July 24, 2020).

$54 I d$.

$55 \mathrm{Id}$.

$56 I d$.

57 Id. Because Justice Gorsuch recused himself from decisions in the case, many have speculated that the Court's actions meant the Court was deadlocked, 4-4, on a decision in Sharp v. Murphy. See, e.g. Adam Liptak, Supreme Court to Rule on Whether Much of Oklahoma Is an Indian Reservation, New York Times Dec. 13, 2019, available at: https://www.nytimes.com/2019/12/13/us/supreme-court-oklahoma-indian-reservation.html 
On April 17, 2019, the Petition for a writ of certiorari and motion for leave to proceed in forma pauperis was filed from the Oklahoma Court of Criminal Appeals by Jimcy McGirt, a pro se defendant.58 Jimcy McGirt was convicted of three sexual offenses by an Oklahoma State Court.59 As in Sharp v. Murphy, Mr. McGirt consistently argued that the State of Oklahoma did not have the authority to prosecute him because he is an enrolled citizen of the Seminole Nation and the alleged crimes occurred within the Muscogee (Creek) Reservation.60 This is because the Major Crimes Act provides that, within "the Indian country," "[a]ny Indian who commits" certain enumerated offenses "against the person or property of another Indian or any other person" "shall be subject to the same law and penalties as all other persons committing any of the above offenses, within the exclusive jurisdiction of the United States."61 Because state courts generally do not have authority to try cases occurring within Indian country, McGirt argued that the Oklahoma courts should not have authority to hear the charges against him as the crimes occurred within Indian country - the Muscogee (Creek) Reservation. Because this case raised essentially the same legal question as Sharp v. Murphy, one may assume that the Court opted to grant certiorari in this case, a case where Justice Gorsuch did not have to recuse himself, rather than rehear Sharp v. Murphy for a second time. But, regardless of the reason, the U.S. Supreme Court granted to petition and motion on December 13, 2019, and oral argument was heard on May 11, 2020.62 The Court released its decision on July 9, 2020, a 5-4 decision in favor of the Petitioner and the majority opinion was authored by Justice Gorsuch.

In reaching its decision, the Court focused on question of whether the alleged crimes took place within the Muscogee (Creek) Reservation and were therefore within Indian country.63 To answer this question, the Court had to delve into the Treaty With the Creeks, Arts. I, XIV, Mar. 24, 1832, 7 Stat. 366, 368 (1832 Treaty), as the 1832 Treaty established the boundaries of the Muscogee (Creek) Reservation. Ultimately, the Court held that "Today we are asked whether the land these treaties promised remains an Indian reservation for purposes of federal criminal law. Because Congress has not said otherwise, we hold the government to its word." 64

In reaching this decision, the Court explained that

No one disputes that Mr. McGirt's crimes were committed on lands described as the Creek Reservation in an 1866 treaty and federal statute. But, in seeking to defend the state-court judgment below, Oklahoma has put aside whatever

58 https://www.supremecourt.gov/DocketPDF/18/18-9526/102351/20190610161914806_00000010.pdf (last accessed July 24, 2020).

59 McGirt v. Oklahoma, 591 U.S. __, 2 (2020).

$60 \mathrm{Id}$.

6118 U. S. C. $\$ 1153(\mathrm{a})$.

62 SCOTUSBlog, McGirt v. Oklahoma, available at: https://www.scotusblog.com/case-files/cases/mcgirt-voklahoma/ (last accessed July 24, 2020).

63 McGirt v. Oklahoma, 591 U.S. ___ 2 (2020) ("the MCA defines the term to include, among other things, "all land within the limits of any Indian reservation under the jurisdiction of the United States Government, notwithstanding the issuance of any patent, and, including rights-of-way running through the reservation." $\S 1151(\mathrm{a}) . ”)$.

64 McGirt v. Oklahoma, 591 U.S. 1 (2020). 
procedural defenses it might have and asked us to confirm that the land once given to the Creeks is no longer a reservation today.65

The Court therefore starts its analysis from the boundaries created by the 1832 Treaty and then works forward in time to determine if the reservation has been diminished or disestablished by Congress. The Court detailed assurances made by the United States to the Creek Nation that the land in question would remain theirs, and also cites to the 1833 Treaty that provided the land was to be the "permanent home" to the Nation.66 Although the Treaties in question did not specifically use the term "Reservation," the Court explained that it had accepted similar language as establishing Reservations in past decisions.67 And, although subsequent congressional actions diminished the size the Reservation, Congress did reaffirm its commitment to maintaining the land for the Creek Nation.68 The Court therefore confirmed the founding and continuation of the Muscogee (Creek) Reservation in the 19th Century.

The Court, however, went on to explain that the United States had broken its treaty promises to the Nation and that the land had been broken up over subsequent years. And, as a result, many non-Indians now owned land within the borders of the Reservation.69 The Court provided the following guidance in determining whether or not the Reservation still existed despite these changes in ownership:

To determine whether a tribe continues to hold a reservation, there is only one place we may look: the Acts of Congress. This Court long ago held that the Legislature wields significant constitutional authority when it comes to tribal relations, possessing even the authority to breach its own promises and treaties. But that power, this Court has cautioned, belongs to Congress alone. Nor will this Court lightly infer such a breach once Congress has established a reservation. 70

The Court affirmed that only Congress can diminish reservation boundaries, and the Court went on to provide historical examples proving that Congress knows how to use language to diminish or disestablish a reservation.71 Oklahoma argued that Congress did exactly that to the Muscogee (Creek) Reservation during the allotment era of the late 18th and early 19th Centuries when Congress opened up tribal lands to allotment and settlement by non-Indians. 72 The Court responds to this argument, however, by explaining that "[m]issing in all this, however, is a statute evincing anything like the "present and total surrender of all tribal interests" in the affected lands."73 In other words, although Congress opened up the Reservation to non-Indian settlement and purchase of lands, there is no congressional act specifically specifying that Congress intended to disestablish the Reservation.

65 McGirt v. Oklahoma, 591 U.S. 3 (2020).

66 McGirt v. Oklahoma, 591 U.S. $4(2020)$.

67 McGirt v. Oklahoma, 591 U.S. 5 (2020).

68 Id. at 5-6. The Court also noted that several subsequent federal laws made mention of the Creek Reservation. $69 \mathrm{Id}$. at 6.

70 Id. at 7 (citing Lone Wolf v. Hitchcock, 187 U. S. 553, 566-568 (1903); Solem v. Bartlett, 465 U. S. 463 , 470 (1984)).

71 Id. at 8 .

72 Id. at $8-9$.

73 Id. at 9. 
Oklahoma argued that, even if the Reservation was not explicitly disestablished, Congress intruded into the Nation's ability to self-govern, such as banning tribal courts. As a result, Oklahoma argued that Congress intended to disestablish the reservation. 74 The Court retorted by explaining that:

But, just as plainly, they [Congress] left the Tribe with significant sovereign functions over the lands in question. For example, the Creek Nation retained the power to collect taxes, operate schools, legislate through tribal ordinances, and, soon, oversee the federally mandated allotment process. And, in its own way, the congressional incursion on tribal legislative processes only served to prove the power: Congress would have had no need to subject tribal legislation to Presidential review if the Tribe lacked any authority to legislate. Grave though they were, these congressional intrusions on pre-existing treaty rights fell short of eliminating all tribal interests in the land.75

The Court also explained that the Five Civilized Tribes Act of 1906 did not disestablish the Reservation or put an end to the tribal government, although the Act did result in significantly more federal intrusion into the Nation's activities.76 Also, the 1906 Act did affirm the Nation's continued existence, and subsequent congressional actions never suggested that the tribal government ceased to exist.77 Starting in the 1930s, the federal policies toward tribal governments changed, and since that time, the Muscogee (Creek) Nation has only grown and prospered.78

Given that Oklahoma could not point to any action of Congress that explicitly disestablished the Muscogee (Creek) Nation, it argued that historical practices and demographic data suggest that the Reservation has been disestablished.79 Oklahoma argued that the Court's decision in Solem $v$. Bartlett should be read as creating a three step test, requiring the court to go through all three tests: 1) congressional statements; 2) contemporary events; and, 3) subsequent events and demographics.80 But, the Court rejects this reading of Solem, explaining that

This is mistaken. When interpreting Congress's work in this arena, no less than any other, our charge is usually to ascertain and follow the original meaning of the law before us. ... That is the only "step" proper for a court of law. To be sure, if during the course of our work an ambiguous statutory term or phrase emerges, we will sometimes consult contemporaneous usages, customs, and practices to the extent they shed light on the meaning of the language in question at the time of enactment. ... But Oklahoma does not point to any ambiguous language in any of the relevant statutes that could plausibly be read as an Act of disestablishment. Nor may a court favor contemporaneous or later practices instead of the laws

$74 I d$. at 13.

75 Id. at 14 (citations omitted).

76 Id. at $14-15$.

77 Id. at 15.

78 Id. at 16.

79 Id. at 17.

$80 \mathrm{Id}$. at 18. 
Congress passed. As Solem explained, "[o]nce a block of land is set aside for an Indian reservation and no matter what happens to the title of individual plots within the area, the entire block retains its reservation status until Congress explicitly indicates otherwise." 465 U. S., at 470 (citing United States v.

Celestine, 215 U. S. 278, 285 (1909)).81

Accordingly, the Court makes clear that there is no reason to consult external sources when the congressional meaning is unambiguous. Given there is no ambiguity in any of the congressional actions taken with regard to the Muscogee (Creek) Reservation, the Court does not need to review subsequent events or demographic data. 82

In the alternative, Oklahoma argues that the Muscogee (Creek) Reservation was never established in the first place.83 Specifically, Oklahoma argues that all the Nation possessed was a dependent Indian community, as a reservation was never explicitly created.84 However, the Court counters that, even accepting this argument at face value, dependent Indian communities are part of Indian country.85 As a result, Oklahoma would lack jurisdiction to prosecute Mr. McGirt regardless of whether the territory is a Reservation or a dependent Indian community, as both qualify as Indian country.86 Oklahoma asserted that because the Nation owned the land in fee, it could not be reservation land, which must be withheld by the federal government from sale. 87 The Court, however, rejected this argument because, even though the Nation held the land in fee, the federal government did preclude it from being sold. 88

Oklahoma offers another argument in the alternative - that it does not matter whether or not the Muscogee (Creek) Nation still exists, as the Major Crimes Act does not apply to the eastern portion of Oklahoma. 89 The State of Oklahoma was formed from two territories - the Oklahoma territory of the west and the Indian territory of the east.90 As a result, the court structure in place between the two territories differed. The Court rejected this argument, however, finding that the Major Crimes Act applied to Oklahoma as soon as it became a state.91

Finally, Oklahoma abandoned legal arguments, and focuses on policy arguments instead. Oklahoma warns "our holding might be used by other tribes to vindicate similar treaty promises. Ultimately, Oklahoma fears that perhaps as much as half its land and roughly 1.8 million of its residents could wind up within Indian country."92 But, the Court responds by explaining that it can only focus on the Treaties currently before it and cannot speculate as to other tribes and treaties. Further, the Court ponders

81 Id. at 18 (citations omitted).

$82 I d$. at 20.

$83 I d$. at 28.

$84 \mathrm{Id}$.

85 Id. at 28-29.

86 Id. at 29.

${ }_{87} I d$. at 30.

88 Id.

$89 \mathrm{Id}$. at 32 .

$90 \mathrm{Id}$.

$91 \mathrm{Id}$. at 33 .

$92 \mathrm{Id}$. at 37 . 
What are the consequences the State and dissent worry might follow from an adverse ruling anyway? Primarily, they argue that recognizing the continued existence of the Creek Reservation could unsettle an untold number of convictions and frustrate the State's ability to prosecute crimes in the future. But the MCA applies only to certain crimes committed in Indian country by Indian defendants. 93

Oklahoma does assert that the Court's decision in favor of affirming the existence of the Muscogee (Creek) Reservation will have far reaching implications beyond application of the Major Crimes Act. But, the Court responds in kind, explaining

Finally, the State worries that our decision will have significant consequences for civil and regulatory law. The only question before us, however, concerns the statutory definition of "Indian country" as it applies in federal criminal law under the MCA, and often nothing requires other civil statutes or regulations to rely on definitions found in the criminal law. Of course, many federal civil laws and regulations do currently borrow from $\$ 1151$ when defining the scope of Indian country. But it is far from obvious why this collateral drafting choice should be allowed to skew our interpretation of the MCA, or deny its promised benefits of a federal criminal forum to tribal members. It isn't even clear what the real upshot of this borrowing into civil law may be. Oklahoma reports that recognizing the existence of the Creek Reservation for purposes of the MCA might potentially trigger a variety of federal civil statutes and rules, including ones making the region eligible for assistance with homeland security, 6 U. S. C. $\$ \$ 601,606$, historical preservation, 54 U. S. C. $\$ 302704$, schools, 20 U. S. C. §1443, highways, 23 U. S. C. $\$ 120$, roads, §202, primary care clinics, 25 U. S. C. $\S 1616 \mathrm{e}-1$, housing assistance, $\$ 4131$, nutritional programs, 7 U. S. C. $\S \S 2012$, 2013, disability programs, 20 U. S. C. $\$ 1411$, and more. But what are we to make of this? Some may find developments like these unwelcome, but from what we are told others may celebrate them.94

The Court does go on to explain that, should such fears become a reality, other legal remedies exist to protect established interests.

Still, we do not disregard the dissent's concern for reliance interests. It only seems to us that the concern is misplaced. Many other legal doctrines-procedural bars, res judicata, statutes of repose, and laches, to name a few-are designed to protect those who have reasonably labored under a mistaken understanding of the law. And it is precisely because those doctrines exist that we are "fre [e] to say what we know to be true ... today, while leaving questions about ... reliance interest[s] for later proceedings crafted to account for them." Ramos, 590 U. S., at (plurality opinion) (slip op., at 24).95

$93 I d$.

94 Id. at $39-40$.

$95 \mathrm{Id}$. at 41 . 
For these reasons, the Court reversed the Oklahoma Court of Criminal Appeals in McGirt v. Oklahoma, and, at the same time, affirmed the Tenth Circuit in Sharp v. Murphy.

\title{
C. The Epilogue (?) or The Known Unknown
}

The full impact of the McGirt decision is only just beginning to play out. In response to dire warnings by the State of Oklahoma and the dissent in the case, Justice Gorsuch opined at the end of the majority opinion that

\begin{abstract}
With the passage of time, Oklahoma and its Tribes have proven they can work successfully together as partners. Already, the State has negotiated hundreds of intergovernmental agreements with tribes, including many with the Creek. See Okla. Stat., Tit. 74, §1221 (2019 Cum. Supp.); Oklahoma Secretary of State, Tribal Compacts and Agreements, www.sos.ok.gov/tribal.aspx. These agreements relate to taxation, law enforcement, vehicle registration, hunting and fishing, and countless other fine regulatory questions. ... No one before us claims that the spirit of good faith, "comity and cooperative sovereignty" behind these agreements, ... will be imperiled by an adverse decision for the State today any more than it might be by a favorable one. 96
\end{abstract}

The majority therefore recognizes that the decision will have repercussions for the relationship between the Muscogee (Creek) Nation (and potentially other Oklahoma Tribes) and the State of Oklahoma, but believes that the relevant parties have the capacity to work through such challenges in a spirit of "cooperative sovereignty."

As predicted, the parties responded incredibly quickly, releasing a "Murphy/McGirt Agreementin-Principle" on July 16, 2020 - only one week after the Court released its decision.97 For all intents and purposes, the proposed Agreement-in-Principle, which was a mere two pages, mirrored existing federal Indian law applicable to other parts of Indian country with regard to tribal civil regulatory and adjudicatory authority.98 The same could not be said with regard to its

\footnotetext{
96 Id. at 41-42.

97 Oklahoma Attorney General, Attorney General and Five Tribes Release Agreement in Principle for Criminal. Civil Jurisdiction (posted July 16, 2020); http://www.oag.ok.gov/attorney-general-and-five-tribes-releaseagreement-in-principle-for-criminal-civil-jurisdiction.

98 For example, the provision on civil regulatory/adjudicatory jurisdiction in Indian country largely mirrors the U.S. Supreme Court's decision in Montana v. United States, where the U.S. Supreme Court held that there is a general presumption against tribal civil regulatory authority over non-Indians on non-Indian land, unless the non-Indian consents to tribal jurisdiction or the actions of the non-Indian threaten the health, safety, and welfare of the Tribe. 450 U.S. 544 (1981); compare with Murphy/McGirt Agreement-in-Principle, 2, available at: http://www.oag.ok.gov/Websites/oag/images/doc\%20-\%202020-07-15\%20-\%20murphy\%20(final\%20\%20agreement-in-principle).pdf (last accessed July 25, 2020) (“Affirm the Five Tribes' civil jurisdiction throughout their respective treaty territories, to be exercised subject to Federal law that generally governs Tribal civil jurisdiction in Indian country. The Five Tribes would accordingly be affirmed in their civil jurisdiction over, for example, matters of self-government and their members but would remain subject to the Federal law that provides, as a general matter, that Tribes do not have civil jurisdiction over non-members outside Indian trust or restricted lands, as described above, except for (1) subject matters for which Federal law specifically grants Tribes jurisdiction; (2) activities of non-members that are part of a consensual relationship, such as contracts, with the
} 
criminal provisions. The agreement was quickly criticized by many in Indian country, and especially Oklahoma tribal members, as surrendering tribal sovereignty because the agreement would allow the state to prosecute crimes that have traditionally been under the exclusive sovereignty of the tribes or the federal government.99 Both the Muscogee (Creek) Nation and Seminole Nation withdrew from the Agreement-in-Principle over concerns that the Agreementin-Principle would surrender aspects of tribal sovereignty that had been affirmed in the Court's decision.100 The Cherokee Nation of Oklahoma's position on the Agreement-in-Principle seems, at the time of writing, to be influx, as the Principal Chief of the Nation originally signed on to the agreement, but, after significant backlash from citizens of the Nation, seems to be open to different courses of action.101 At best, it would seem that tribal support for the Agreement-inPrinciple is waning.

At the same time this is happening in Oklahoma between the State of Oklahoma and Tribes located within Oklahoma, a rumor has emerged suggesting that some in Congress are working on legislation that would terminate reservations in Oklahoma.102 Given Congress has plenary authority in Indian country, 103 it certainly possesses the authority to disestablish reservations in Oklahoma, as Justice Gorsuch hinted at in his opinion.104 But, given the political realities of Congress at the moment, whether such congressional action would actually manifest as a reality is a question mark.

The weeks following the Court's decision in McGirt have been a roller coaster ride in terms of tribal-state, state-federal, and tribal-federal relations for the parties involved. While the Court's decision answered the immediate question of the current status of the Muscogee (Creek) Reservation's boundaries, it opened many other questions that remain to be answered - some answers will be easier to come by than others.

\section{Status Quo Meets McGirt: How the Court's Decision May Impact Natural Resource Development in Oklahoma and Beyond}

Tribe; or (3) conduct of non-members that threatens Tribal self-governance or the economic security, health, or welfare of the Tribe.").

99 See e.g. Zac Russell, Cherokee Nation Won't Surrender its Sovereignty, Indianz.com (July 24, 2020);

https://www.indianz.com/News/2020/07/24/zac-russell-cherokee-nation-can-protect.asp.

100 Acee Agoyo, No 'surrender': Muscogee (Creek) Nation stands firm on sovereignty after historic Supreme Court win, Indianz.com (July 20, 2020); available at: https://www.indianz.com/News/2020/07/20/no-surrender-muscogeecreek-nation-stand.asp.

${ }_{101}$ Chad Hunter, Cherokee Nation leaders spar over McGirt ruling response, Cherokee Phoenix (July 22, 2020); https://www.cherokeephoenix.org/Article/index/145053.

102 Acee Agoyo, National Congress of American Indians stands strong against efforts to erode tribal sovereignty, Indianz.com (July 23, 2020); available at: https://www.indianz.com/News/2020/07/23/national-congress-ofamerican-indians-st-1.asp?fbclid=IwAR1GIV11UMWj8n0U0KT017UCTV14reFynQZEA0KwGiJ3_Xur4ySXw_viGU.

103 United States v. Kagama, 118 U.S. 375 (1886).

104 McGirt v. Oklahoma, 591 U.S. ___ 42 (2020) (“And, of course, should agreement prove elusive, Congress remains free to supplement its statutory directions about the lands in question at any time. It has no shortage of tools at its disposal."). 
With background on the existing law impacting natural resource development and an understanding of what and why the Court ruled in McGirt, this Part now examines how the Court's decision will likely (not) impact natural resource development, including oil and gas development, within the recognized reservation borders of the Tribes impacted by the Court's decision. There are a couple of things that the McGirt decision clearly does not effect, and so these will not be discussed below. First, anyone who currently owns title in land within the reaffirmed borders of the Muscogee (Creek) Reservation will not lose their property as a result of this decision.105 It is not uncommon for non-Indians and non-Indian entities to own land within tribal reservations. Similarly, taxes based on land ownership/status will likely not be affected by this decision.106 This Part, however, will address those aspects of the status quo that may be affected by the McGirt decision, such as: criminal jurisdiction, environmental regulation, some taxes, oil and gas regulation, and rights of way. The Part ends with a section that speculates on how the McGirt decision may impact other areas of federal Indian law, such as in the assertion of tribal treaty rights, recognition of tribal sovereignty, and the federal government's willingness to recognize broken promises.

\section{A. Criminal Jurisdiction}

As the above discussion of the drama that unfolded in the weeks following the McGirt decision suggests, the many seem to be currently focused on the decision's impact on criminal jurisdiction within Indian country, as specifically the reservations impacted by the decision. 107 To understand the potential impact of the decision, it is helpful to briefly review criminal jurisdiction in Indian country. Exclusive tribal criminal authority began to fray in 1817 , when Congress passed the General Crimes Act which unilaterally imposed federal criminal jurisdiction on crimes committed by non-Indians against Indians in Indian country.108 The intrusion continued with the passage of the Major Crimes Act (MCA) in 1885, which was the focus of the Court's analysis in the McGirt decision.109 The law unilaterally imposes federal criminal

105 Grant D. Crawford, Former tribal justice, law school dean says Supreme Court's McGirt ruling has no affect on property ownership, taxation, CNHI LLC (July 18, 2020), https://www.cnhi.com/featured_stories/former-tribaljustice-law-school-dean-says-supreme-courts-mcgirt-ruling-has-no-affect-on/article_69a44cd6-c9be-11ea-ae3af753c26e583b.html ("Many concerns have been about the ownership of land, and taxation within the reservation. Leeds said the ruling in no way affects ownership and title of land. "We're talking about reservation boundaries for jurisdictional purposes," she said. "So all of these pieces of land that are already on the county tax rolls, those aren't coming off. There's already federal legislation that says after the allotment - after restriction is lifted from those lands - those lands become fully taxable."').

106 Grant D. Crawford, Former tribal justice, law school dean says Supreme Court's McGirt ruling has no affect on property ownership, taxation, CNHI LLC (July 18, 2020), https://www.cnhi.com/featured_stories/former-tribaljustice-law-school-dean-says-supreme-courts-mcgirt-ruling-has-no-affect-on/article_69a44cd6-c9be-11ea-ae3af753c26e 583b.html.

${ }_{107}$ Although the decision was specific to the Muscogee (Creek) Reservation and the histories of the Tribes in Eastern Oklahoma are different, many believe that the histories of the "Five Civilized Tribes" in the area are similar enough that the McGirt decision will potentially impact the reservation boundaries of these other Tribes - such as the Cherokee Nation of Oklahoma. See e.g. Grant D. Crawford, Former tribal justice, law school dean says Supreme Court's McGirt ruling has no effect on property ownership, taxation, CNHI LLC (July 18, 2020), https://www.cnhi.com/featured_stories/former-tribal-justice-law-school-dean-says-supreme-courts-mcgirt-rulinghas-no-affect-on/article_69a44cd6-c9be-11ea-ae3a-f753c26e583b.html.

10818 U.S.C. $\$ 1152$ (2012).

10918 U.S.C. $\$ 1153$. 
jurisdiction on crimes committed by Indians who are accused of felony-level crimes. While tribal nations retain concurrent authority over such Indians, the imposition of the federal system has served to complicate and confuse the direct application of justice to those who commit violent acts. 110

Tribal governments themselves are limited in the application of tribal criminal law. There are two major restrictions on tribal criminal authority pertinent to the discussion of natural resource development in Indian country. First, tribal governments are limited in the length of incarceration and the imposition of fines as a result of the Indian Civil Rights Act of 1968.111 Until the passage of the Tribal Law and Order Act (discussed below), the maximum penalties that could be imposed by a tribal court were 1 year and/or a 5,000-dollar fine - for any crime, including sexual assault and sex trafficking. 112

Perhaps more pertinent to the question of energy extraction is a prohibition on the application of tribal criminal jurisdiction over non-Indians. In the 1978 case Oliphant v. Suquamish Indian Tribe, the Supreme Court stripped the authority of tribal nations to prosecute non-Indians - for any crime. 113 The Oliphant case involved the criminal actions of two non-Indians on the Suquamish Indian reservation. 114 When the Suquamish tribe sought to prosecute the two nonIndians, they protested tribal jurisdiction, arguing that, as non-Indians, they should not be subject to tribal jurisdiction (despite the fact that the crimes had been committed on the reservation). 115 In Oliphant, the Supreme Court ruled that tribal governments, by virtue of their dependence on the federal government, had lost certain attributes of inherent sovereignty, including the authority to prosecute non-Indians.116 As a result, only the federal government (or a state government pursuant to special delegation) can prosecute non-Indians accused of a violent crime.

The federal government has released a variety of different crime reports which universally come to the same conclusion - that Native people experience some of the highest rates of crime in the Nation, and most of that crime is being committed by non-Indians.117 The 2016 federal report concluded that over $80 \%$ of Native women will experience some form of violent crime in their lives, and that over $56 \%$ of Native women will experience some form of sexual violence in their lifetimes.118 The 2016 report also concluded that over $90 \%$ of Native people report that they have been the victims of inter-racial violence - that is, a victim of a non-Indian perpetrator.119

110 Kevin K. Washburn, What the Future Holds: The Changing Landscape of Federal Indian Policy, 130 HARV. L. REV. 200, 229 (2017) (noting that the blurred lines between tribal and federal authority produce complex questions).

111 Indian Civil Rights Act, 25 U.S.C. §§ 1301-1304 (2012 \& Supp. I 2013).

$112 I d$.

113 Oliphant v. Suquamish Indian Tribe, 435 U.S. 191, 212 (1978).

$114 \mathrm{Id}$. at 194.

$115 \mathrm{Id}$.

$116 \mathrm{Id}$. at 199.

117 See, e.g. STEVEN W. PERRY, BUREAU OF JUSTICE STATISTICS, AMERICAN INDIANS AND CRIME: A BJS STATISTICAL PROFILE, 1992-2002; PATRICIA TJADEN \& NANCY THOENNES, U.S. DEP'T OF JUSTICE, FULL REPORT OF THE PREVALENCE, INCIDENCE, AND CONSEQUENCES OF VIOLENCE AGAINST WOMEN (2000); ANDRE ROSAY, ViOLENCE AGAINST AMERICAN INDIAN AND ALASKA NATIVE WOMEN AND MEN (2016).

118 Andre Rosay, Violence Against American Indian And Alaska Native Women And Men (2016). 119 ANDRe Rosay, Violence Against American Indian ANd Alaska Native Women AND Men (2016). 
This is relevant to natural resource development, because such development requires that significant numbers of non-Native people move (at least temporarily) to the lands in or near reservations to effectuate energy development through the development of pipeline or the industry of fracking.120 Many studies have concluded that violence against Native women and children increases when the exploitation of land brings large numbers of non-Native men to tribal jurisdictions. 121

Two major pieces of legislation were adopted to address these concerns - the Tribal Law and Order Act (TLOA) of 2010122 and the 2013 reauthorization of the Violence Against Women Act (VAWA).123 Both laws were intended to improve the response to violent crime in Indian country by enhancing the federal response to crime while also lifting some of the restrictions on tribal authority. VAWA 2013 was groundbreaking - for the first time since Oliphant, the federal government authorized tribal nations to exercise jurisdiction over non-Indians - but only in cases of domestic violence. While spouses and dating partners can be prosecuted, non-Indians who have not been in a relationship with their victims are still exempt from tribal criminal jurisdiction - a category of people which would include those employed by energy companies that seek to exploit tribal lands for oil and gas, or other forms of natural resource development.

As a result of VAWA and the existing criminal jurisdictional scheme in Indian country, companies engaged in natural resource development in Indian country could experience a couple of changes related to criminal matters following the McGirt decision. First, any Indians employed by such companies who are accused of crimes could find themselves subject to tribal and/or federal criminal jurisdiction 124 subject to the limitations discussed above. Second, because of VAWA, any non-Indians can fall under tribal criminal jurisdiction if they commit domestic violence against spouses or dating partners who are citizens of the tribes. 125 It is

120 See Sari Horwitz, Dark Side of The Boom, WASH. Post (Sept. 28, 2014), http://www.washingtonpost.com/sf/national/2014/09/28/dark-side-of-the-boom/?utm_term=.142685688eee; Aura Bogado, Fracking, Tribal Lands, and The Bureau of Land Management: What Happens Next?, GRIST (Mar. 2, 2016), https://grist.org/climate-energy/fracking-tribal-lands-and-the-bureau-of-land-management-what-happensnext/.

121 See id.

122124 Stat. 2258 (2010).

123127 Stat. 54 (2013).

124 United States v. Lara, 541 U.S. 193 (2004) (holding that tribes possess criminal jurisdiction over all Indians regardless of whether or not the Indian is a citizen of the tribe at issue).

125 This is particularly relevant because many communities impacted by explosive natural resource development have seen "man camps" (temporary communities of transient workers who tend to be overwhelmingly male) pop up and instances of violence, including sexual assault and domestic violence increase. Kathleen Finn et al., Responsible Resource Development and Prevention of Sex Trafficking: Safeguarding Native Women and Children on the Fort Berthold Reservation, 40 HARVARD J. LAW GEND. 1, 2 (2017)( noting that "rapid oil and gas development have brought an unprecedented rise of violent crime on and near the Fort Berthold reservation... Specifically, the influx of well-paid male oil and gas workers, living in temporary housing often referred to as "man camps," has coincided with a disturbing increase in sex trafficking of Native women."). See also REPORT OF THE SPECIAL RAPPORTEUR ON THE RIGHTS OF INDIGENOUS PEOPLES ON HER MISSION TO THE UNITED STATES OF AMERICA, 12-13 (2017),

https://www.ushrnetwork.org/sites/ushrnetwork.org/files/sr_on_indigenous_peoples_final_us_country_visit_report.p df. (noting that "Rapid development of the Bakken Formation since 2011 has attracted thousands of oil workers to North Dakota. One of the effects of the influx of oil and gas workers to the area has been a dramatic increase in 
therefore possible that entities engaged in natural resource development within the territories affected by the Court's McGirt decision could find that their employees will have greater interactions with tribal and federal courts.

\section{B. Environmental regulation}

Having explained how the McGirt decision potentially impacts criminal jurisdiction within the affected territories, it is helpful to now examine how the decision potentially impacts environmental regulation, as natural resource development in Indian country typically is subject to environmental regulation. As an initial starting point, tribes may enact laws as a result of their inherent tribal sovereignty, 126 and, unless a federal environmental regulation of general application applies - tribes may enact their own tribal environmental regulations. Contact with foreign sovereigns certainly influenced tribal governments.127 Despite this contact, however, tribal governments retain the status of independent, sovereign governments. As the United States Supreme Court acknowledged in Worcester v. Georgia, tribes are "distinct, independent political communities."128 Inherent tribal sovereignty persists today. "Tribal powers of selfgovernment are recognized by the Constitution, legislation, treaties, judicial decisions, and administrative practice." 129 Unless federal law divests a tribe of its inherent sovereignty, the tribe's sovereignty remains intact.130 Tribes maintain sovereign authority over their members and territory to the extent not limited by federal law.131

Nonetheless, the nature of tribal sovereignty has changed over time, largely as a result of tribes' interactions with the federal government. Today, tribes maintain those aspects of sovereignty that have not been removed by virtue of treaty, statute or "by implication as a necessary result of

violent crime, generally, and a notable increase in trafficking of Native women and children.") The United States Department of State has also acknowledged the problem, noting that "Service providers in areas near camps surrounding large-scale oil extraction facilities, such as the Bakken oil fields in North Dakota in the United States, have reported that sex traffickers have exploited women in the area, including Native American women." UNITED States Department of State, The Link BetweEn EXTRACTIVE INDUSTRIES AND SEX TrafFicKING (2017), https://www.state.gov/documents/organization/272964.pdf.

126 Cohen's Handbook of Federal Indian Law, ch. 10 (Nell Jessup Newton, et al. eds., 2012).

127 For example, the Anglo court systems of the federal government and state governments influenced the development of tribal courts following first contact. See generally VINE DELORIA, JR. \& CLIFFORD M. LYTLE, AMERICAN INDIANS, AMERICAN JUSTICE (1983).

12831 U.S. 515, 559 (1832). The Worcester Court went on to explain that even though the Court had described tribes as "domestic dependent nations" in Cherokee Nation v. Georgia, 30 U.S. 1, 17 (1831), that tribal sovereignty still existed and tribes were not dependent on federal law. Cohen's Handbook of Federal Indian Law § 4.01[1][a] (Nell Jessup Newton, et al. eds. Lexis Nexis 2005 ed.) (citing Worcester, 31 U.S. at 559).

129 Cohen's Handbook of Federal Indian Law, § 4.01[1][a] (Nell Jessup Newton, et al. eds., 2012).

$130 \mathrm{Id}$.

131 Cohen’s Handbook of Federal Indian Law § 4.01[1][b] (Nell Jessup Newton, et al. eds., 2005) citing Worcester, 31 U.S. at 555 (absent tribal or federal approval " $[\mathrm{t}]$ he Cherokee nation, then, is a distinct community occupying its own territory, with boundaries accurately described, in which the laws of Georgia can have not force"); Ex parte Crow Dog, 109 U.S. 556 (1883) (affirming exclusive tribal authority to impose criminal punishment on tribal members absent federal law to the contrary); Fisher v. Dist. Ct., 424 U.S. 382 (1976) (upholding exclusive tribal jurisdiction over an adoption proceeding in which all parties were tribal members and reservation residents); 25 U.S.C. § 1911(a) (reinforcing the Fisher holding by declaring exclusive tribal jurisdiction over certain child custody matters involving children who are tribal members or eligible to be tribal members, so long as the children are domiciled or residing on the reservation, or wards of a tribal court). 
their dependent status." 132 Accordingly, any examination of tribal authority should start with the presumption that the tribe in question possesses sovereignty, unless the tribe has been divested of its sovereignty by the federal government.133

In addition to inherent tribal sovereignty, Congress may also delegate environmental federal authority to tribes through either a treaty or statute.134 The ability of Congress to delegate authority to tribes is especially important in the context of environmental regulatory law. Because many federal environmental and energy laws are usually considered to be laws of general application, they apply in Indian country, unless their application would directly interfere with tribal sovereignty.135 As a result, the federal Environmental Protection Agency (EPA) has the authority to implement federal environmental laws in Indian country.136 However, the EPA has interpreted some federal environmental statutes, such as the Clean Water Act, "not as delegating or conferring federal power on tribes, but as authorizing tribes to implement federal programs within the scope of their inherent [tribal] powers."137 Conversely, under the Clean Air Act, the EPA interprets the Act as a delegation of authority to tribes. 138 Therefore, under several federal environmental statutes, tribes may choose to administer the federal environmental programs and standards through tribes-as-states (TAS) mechanisms.139 The TAS provisions of major federal environmental statutes, such as the Clean Air Act,140 Clean Water Act,141 and Safe Drinking Water Act, 142 allow tribes to act as states for purposes of implementing the statute under the cooperative federalism scheme.143 Accordingly, in situations where one of these regulations may apply to natural resource development, the tribe could have a say in how the regulation is applied within its territorial borders if it has TAS authority.

Jurisdictional uncertainty sometimes arises in relation to a tribe's authority over the actions of non-members and non-Indians acting within the tribe's territory. This is relevant to natural resource development, as it is not uncommon for the developer to be non-Indian acting on land

132 United States v. Wheeler, 435 U.S. 313, 323 (1978).

133 Cohen's Handbook of Federal Indian Law § 4.01[1][a] (Nell Jessup Newton, et al. eds., 2005).

134 Id. "Whether such statutes actually delegate federal power, as opposed to affirming or recognizing inherent power, is a matter of congressional intent." Id.

135 Fed. Power Comm'n v. Tuscarora Indian Nation, 362 U.S. 99 (1960) (explaining that federal laws of general application apply to Indian country); Cohen's Handbook of Federal Indian Law, § 10.01[2][a] (Nell Jessup Newton, et al. eds., 2012). However, the application of federal environmental laws does not displace the ability of tribes to enact environmental laws. $I d$. at $§ 10.01[2][\mathrm{b}]$.

136 Cohen's Handbook of Federal Indian Law, § 10.01[2][a] (Nell Jessup Newton, et al. eds., 2012).

137 Id. (citing 56 Fed. Reg. 64,876, 64,880 (1991)). Moreover, tribal inherent sovereignty to enact environmental laws is not displaced by federal environmental law. For example, the Safe Drinking Water Act states that nothing in the Act's 1977 Amendments "shall be construed to alter or affect the state of American Indian lands or water rights nor to waive any sovereignty over Indian land guaranteed by treaty of statute.” 42 U.S.C. § 300j-6(c)(1) (2012). 138 See, e.g., WAyne NASTRI, Regional Administrator, EnVtl. Prot. AgEnCy Region 9, ELIGIBILITY DETERMinAtion FOR THE NAVAJO NATION FOR TREATMENT IN THE SAME MANNER AS A STATE FOR PURPOSES OF THE ClEAN AIR ACT TITLE V, 40 CFR PART 71 PROGRAM, https://www.epa.gov/sites/production/files/201507/documents/navajotas.pdf (last visited May 6, 2018).


LAW 227 (3d ed. 2013).

14042 U.S.C. $\$ 7601(\mathrm{~d})(2)(2012)$.

14133 U.S.C. $\S 1377(\mathrm{e})(2012)$.

14242 U.S.C. $\$ 300 j-11(b)(1)$.

143 Id. 
owned by a non-Indian In the civil regulatory context, this is because tribes' have been divested of their inherent sovereignty over non-citizens unless certain conditions exist.144 In Montana $v$. United States, the U.S. Supreme Court considered the extent of the Crow Nation's inherent sovereignty over non-Indians.145 Specifically, the Crow Nation wished to regulate the hunting and fishing of non-Indians on non-Indian land located within the Nation's territory. 146 Ultimately, because of implicit divestiture of the tribe's inherent sovereignty, 147 the Court determined that tribes do not have authority to regulate the hunting and fishing of non-Indians owning fee land 148 within the Crow Nation's reservation boundaries. 149

However, despite the implicit divestiture of tribal inherent sovereignty over non-Indians on nonIndian fee land within reservation boundaries, the Court acknowledged that tribes may regulate the activities of such individuals under two circumstances. First, tribes may regulate the activities of individuals who have entered into "consensual relationships with the tribe or its members." 150 Second, a tribe retains the "inherent power to exercise civil authority over the conduct of non-Indians on fee lands within its reservation when that conduct threatens or has some direct effect on the political integrity, the economic security, or the health or welfare of the tribe." 151

Notably, the Montana decision involved the actions of non-Indians living on non-Indian owned land within the Nation's territory. It may therefore be argued that tribes have more authority to regulate the activities of non-members and non-Indians on tribally-controlled land within the tribe's territory. However, the United States Supreme Court's decision in Nevada v. Hicks casts doubt on this assumption.152 In Hicks, the Court considered whether the Fallon Paiute-Shoshone Tribes had jurisdiction over Mr. Hicks' civil claim against Nevada game wardens in their individual capacities. 153 Hicks, a tribal citizen, alleged that when searching his on-reservation property, the Nevada game wardens violated certain tribal civil provisions (in addition to

144 Montana v. United States, 450 U.S. 544 (1981). Tribes' criminal jurisdiction is generally limited to Indians. Oliphant v. Suquamish Tribe, 435 U.S. 191 (1978).

145 Montana v. United States, 450 U.S. 544 (1981).

$146 \mathrm{Id}$,

147 Id. See also Bruce Duthu, Implicit Divestiture of Tribal Powers: Locating Legitimate Sources of Authority in Indian Country, 19 AM. INDIAN. L. REV. 353 (1994). "According to this theory, courts can rule that, in addition to having lost certain aspects of their original sovereignty through the express language of treaties and acts of Congress, tribes also may have been divested of aspects of sovereignty by implication of their dependent status."

Kevin Gover \& James B. Cooney, Cooperation Between Tribes and States in Protecting the Environment, 10 NAT. RESOURCES \& ENV'T 35 (1996).

148 Since Montana, the Supreme Court has also considered the ability of tribe's to regulate the conduct of nonmembers and non-Indians on other types of lands. For example, in Strate v. A-1 Contractors, 520 U.S. 438 (1997), the Court held that the Indian tribe did not possess the inherent sovereignty to adjudicate a civil complaint arising from an accident between two non-Indians on a state highway within the tribe's reservation boundaries. The State Court explained that "[a]s to nonmembers, we hold, a tribe's adjudicative jurisdiction does not exceed its legislative jurisdiction." 520 U.S. at 453.

149 Montana, 450 U.S. at 564-65 (holding that the "exercise of tribal power beyond what is necessary to protect tribal self-government or to control internal relations is inconsistent with the dependent status of the tribes, and so cannot survive without express congressional delegation....").

150 Id. at 565.

151 Id. at 566.

152533 U.S. 353 (2001).

$153 \mathrm{Id}$. 
violating federal law). In concluding that the tribal court did not have jurisdiction to hear the tribal-law based claims, the Court found that the Montana exceptions did not apply.154 It may therefore be argued that the Court implicitly suggested in Hicks that Montana applied to the actions of non-members and non-Indians within Indian country regardless of the status of land where the activity occurred.

Based on the foregoing, the McGirt decision would impact civil environmental regulation within the affected territory by applying the framework described above to natural resource development. So, the affected Tribes would generally have regulatory jurisdiction over their citizens within their territories, but not over non-citizens owning fee land within the same territory.155 Because of their inherent sovereignty, tribes generally have regulatory authority over their citizens within their physical territory. Tribes generally do not have inherent sovereignty over and therefore lack jurisdiction over non-Indians acting on non-Indian land within tribal territory, 156 unless one of the two Montana exceptions applies. Tribes may have regulatory authority in such circumstances if the non-Indians or non-members in question have consented to tribal jurisdiction or if the non-Indian conduct "threatens or has some direct effect on the political integrity, the economic security or the health or welfare of the tribe." 157 However, through delegated authority, such as the TAS provisions of many federal environmental statutes, tribes may have jurisdictional authority over non-members and nonIndians. Depending on the whether the affected Tribe has enacted tribal environmental laws and on whether it has TAS under federal environmental laws, 158 an entity engaged in natural resource development within the affirmed tribal borders of the McGirt decision could find itself having significantly more interaction with tribal environmental law and federal law that incorporates tribal preferences through the TAS framework.

Interestingly, within two weeks of the Court's decision in McGirt, the State of Oklahoma petitioned the EPA to allow it to continue to regulate environmental programs across areas that

154533 U.S. at 355-69, 374-75.

155 As support for this conclusion, the controversial Murphy/McGirt Agreement-in-Principle, discussed above, certainly appeared to contemplate the application of the Montana presumption and its two exceptions.

Murphy/McGirt Agreement-in-Principle, 2, available at: http://www.oag.ok.gov/Websites/oag/images/doc\%20\%202020-07-15\%20-\%20murphy\%20(final\%20-\%20agreement-in-principle).pdf (last accessed July 25, 2020) ("Affirm the Five Tribes' civil jurisdiction throughout their respective treaty territories, to be exercised subject to Federal law that generally governs Tribal civil jurisdiction in Indian country. The Five Tribes would accordingly be affirmed in their civil jurisdiction over, for example, matters of self-government and their members but would remain subject to the Federal law that provides, as a general matter, that Tribes do not have civil jurisdiction over non-members outside Indian trust or restricted lands, as described above, except for (1) subject matters for which Federal law specifically grants Tribes jurisdiction; (2) activities of non-members that are part of a consensual relationship, such as contracts, with the Tribe; or (3) conduct of non-members that threatens Tribal self-governance or the economic security, health, or welfare of the Tribe.").

156 Although Montana involved the activities of non-Indians on non-Indian fee land suggesting that the status of the land plays a role in the determination of jurisdiction, Nevada v. Hicks muddies the analysis of tribal jurisdiction. This is because the Hicks Court applied the Montana exceptions to a situation where the alleged wrongful activity occurred on property owned by a tribal member.

$157 \mathrm{Id}$.

158 See Elizabeth Kronk Warner, Examining Tribal Environmental Law, 39 Columbia Journal of Environmental Law 42 (2014) (discussing tribal environmental laws applicable in Oklahoma); Elizabeth Kronk Warner, Tribes as Innovative Environmental "Laboratories”, 86 University of Colorado Law Review 789 (2015) (discussing tribal innovations under the TAS framework). 
were Indian Territory prior to Oklahoma becoming a state. 159 Typically, states do not have the ability to engage in environmental regulation within Indian country, as either the EPA or the Tribes through TAS status will engage in such regulation. 160 However, under the Safe, Accountable, Flexible, Efficient Transportation Equity Act (SAFETEA) of 2005, the EPA does have the authority to grant Oklahoma's request.161 If EPA should grant Oklahoma's request, Oklahoma's environmental regulations would continue to govern the affected territory, although tribal environmental laws could still apply where they are not pre-empted by the federal environmental statutes.

\section{Taxation}

As mentioned above, the McGirt decision will unlikely affect taxes based on land ownership/status.162 However, there could be some impacts to the taxes applied to natural resource development within Indian country. It is therefore helpful to briefly review the existing taxation scheme in place. A long-standing rule of construction of tax laws provides that "to be valid, exemptions to tax laws should be clearly expressed." 163 In some cases, Indian interests have been expressly exempted from general tax laws.164 In other cases, as in Squire, the courts have been willing to find congressional intent to exempt Indian interests from taxation where the exemption is not express. 165

Under the test articulated in Squire, income which is derived directly from allotments held in trust is not subject to federal taxation. "Income is derived directly if is generated principally from the use of reservation land and resources. It is not derived directly if was earned primarily through a combination of taxpayer labor, the sale of goods produced off the reservation, and improvements constructed on the trust land."166 Income is not directly derived if it is attributable primarily to use of the capital improvements constructed on the land and the individual's management of those assets or business activities related to those assets. 167 Using these or similar formulations of the "derived directly" prong, courts have held that income which allottees earned from bonuses and royalties on minerals, from the rental or sale of crops, or from the sale or

159 Jack Money, Oklahoma seeks continued authority to oversee environmental programs in state's Indian territories, The Oklahoman (July 24, 2020), available at: https://oklahoman.com/article/5667451/oklahoma-seekscontinued-authority-to-oversee-environmental-programs-in-states-indian-territories.

160 EPA, Direct Implementation in Indian Country, available at: https://www.epa.gov/tribal/direct-implementationindian-country (last accessed July 29, 2020); State of Washington, Department of Ecology v. United States Environmental Protection Agency, 752 F.2d 1465 (9th Cir. 1985) (holding that EPA's determination that state environmental regulations do not apply within Indian country was reasonable).

161 Pub. L. 109-59.

162 Grant D. Crawford, Former tribal justice, law school dean says Supreme Court's McGirt ruling has no affect on property ownership, taxation, CNHI LLC (July 18, 2020), https://www.cnhi.com/featured_stories/former-tribaljustice-law-school-dean-says-supreme-courts-mcgirt-ruling-has-no-affect-on/article_69a44cd6-c9be-11ea-ae3af753c26e583b.html.

163 Squire v. Capoeman, 351 U.S. 1, 6 (1956).

164 Id.

165 See generally Squire v. Capoeman, 351 U.S. 1 (1956).

166 Dillon v. United States, 792 F.2d 849 (9th Cir. 1986).

167 Critzer v. United States, 597 F.2d 708 (Ct. Cl. 1979). 
exchange of livestock, is tax exempt.168 As a result of these decisions, for a tribal member who is engaging in natural resource development on their allotment, they will be exempt from federal taxes, but such exception would have likely existed prior to the McGirt decision at the Indian would have been doing such development on their allotment.

In terms of tribal taxation, tribes generally maintain the authority to tax their tribal members. In terms of taxation, the controversies are more likely to come up in the context of tribes attempting to tax non-Indian entities doing business within their territories. This was exactly the issue in Merrion v. Jicarilla Apache Tribe.169 In Merrion, 21 lessees of tribal lands, who were engaged in natural resource development (primarily oil and gas developed), sued to challenge the Tribe's application of a severance tax on "any oil and natural gas severed, saved and removed from Tribal lands."170 Following the revision of the Tribe's constitution, the Tribe sought to apply the severance tax against the lessees that were already engaged in development on the reservation.171 The Court ultimately held that the Tribe could apply the severance tax, explaining that:

In Washington v. Confederated Tribes of Colville Indian Reservation, 447 U.S. 134 (1980) (Colville), we addressed the Indian tribes' authority to impose taxes on nonIndians doing business on the reservation. We held that "[the] power to tax transactions occurring on trust lands and significantly involving a tribe or its members is a fundamental attribute of sovereignty which the tribes retain unless divested of it by federal law or necessary implication of their dependent status." The power to tax is an essential attribute of Indian sovereignty because it is a necessary instrument of self-government and territorial management. This power enables a tribal government to raise revenues for its essential services. The power does not derive solely from the Indian tribe's power to exclude non-Indians from tribal lands. Instead, it derives from the tribe's general authority, as sovereign, to control economic activity within its jurisdiction, and to defray the cost of providing governmental services by requiring contributions from persons or enterprises engaged in economic activities within that jurisdiction.

The petitioners avail themselves of the "substantial privilege of carrying on business" on the reservation. They benefit from the provision of police protection and other governmental services, as well as from "'the advantages of a civilized society'" that are assured by the existence of tribal government. Numerous other governmental entities levy a general revenue tax similar to that imposed by the Jicarilla Tribe when they provide comparable services. Under these circumstances, there is nothing exceptional in requiring petitioners to contribute through taxes to the general cost of tribal government.172

168 Big Eagle v. United States, 300 F.2d 765 (Ct. Cl. 1962); United States v. Daney, 370 F.2d 791 (10th Cir. 1966); Rev. Rul. 62-16, 1962-1 C.B. 7.

169455 U.S. 130 (1982).

$170 I d$.

$171 I d$.

172 Id. 
As a result of the Merrion decision, 173 it is highly likely that the Tribes affected by the McGirt decision could enact a severance tax against any lessees engaged in natural resource development within the recently affirmed reservation borders of the Tribes. Imposition of a severance tax, however, would be likely limited to land that is held in trust status.174 As a result, costs related to taxation could increase for natural resource development entities, should Tribes decide to apply severance taxes as the Tribe did in Merrion. Interestingly, a Tribe's application of a severance tax does not preclude the state from also taxing a non-tribal entity doing work within Indian country.175 As a result, a natural resource development entity doing work on tribal trust land within a tribe's reservation could potentially find itself taxed by both the tribe and the state.

\section{Oil and Gas leasing}

The federal government plays a significant role related to energy development within Indian country. As indicated above, federal regulatory statutes tend to be statutes of general applicability, and, therefore, several federal statutes directly apply to such development, including the Indian Mineral Leasing Act, 176 Indian Mineral Development Act, 177 Energy Policy Act of 2005,178 Rights of Way Act, 179 and Long-Term Leasing Act, 180 to name a few. Under the Indian Mineral Leasing and Indian Mineral Development Acts, the Secretary of the Interior is required to approve all oil, gas, and geothermal leases.181 Leases for renewable energy projects must typically be approved under the Long-Term Leasing Act.182 Further, if transmission lines or pipelines are included in the project, then the Secretary must approve the rights-of-way for

173 After the Merrion decision, some argued that the reason the Court held the way it did is because the Secretary of the Interior approved the Tribe's constitutional revision, and, therefore, implicitly approved the taxation. The argument, therefore, was that this was a federal delegation to the Tribe and not truly a vestige of tribal sovereignty. However, this argument was rejected by the Court in its decision in Kerr-McGee Corp. v. Navajo Tribe of Indians, 471 U.S. 195 (1985). In Kerr-McGee Corp., the Court was presented with facts very similar to those in Merrion, but there was an important factual difference because the Secretary of the Interior did not approve the Tribe's constitutional revision (there was no requirement for such approval in the prior constitution). Despite this factual different, the Court still determined that the Tribe had the right to apply the taxes. Id.

174 Atkinson Trading Co., Inc. v. Shirley, 532 U.S. 645 (2001) (rejecting the ability of the Navajo Nation to require a hotel located on non-Indian fee land within the borders of the Reservation to collect a hotel occupancy tax).

175 Cotton Petroleum Corp. v. New Mexico, 490 U.S. 163 (1989). Notably, however, post-Cotton Petroleum cases in the lower federal courts have found state taxes on non-Indians doing business within Indian country preempted where there is a comprehensive federal scheme that leaves no room for state regulation or services. See Quinault Indian Nation v. Grays Harbor County, 19 Indian. L. Rep. 3176 (W.D. Wash. 1989) [1992] (state compensating tax on the sale of forest lands to a tax-exempt entity preempted). See also Gila River Indian Community v. Waddell, 967 F.2d 1404 (9th Cir. 1992) (reversing trial court's dismissal of tribe's suit to enjoin state transaction privilege tax on ticket revenues); Cabazon Band of Mission Indians v. Wilson, 37 F.3d 430 (9th Cir. 1994) (state tax on off-track betting activities on tribal lands preempted by the Indian Gaming Regulatory Act). Although these lower court cases have adhered to the traditional preemption analysis, none of them has involved state taxation of mineral lessees.

17625 U.S.C. $\S 398$ (2012).

17725 U.S.C. $\$ \S 2101-08$.

17825 U.S.C. $\$ \S 3502$ et seq.

17925 U.S.C. $\S \S 311-28$.

18025 U.S.C. $\S 415$.

18125 U.S.C. $\$ \S 398,2103$.

18225 U.S.C. $\$ 415$ (a). 
those projects.183 Under the Energy Policy Act of 2005 and the HEARTH Act, if tribes have the necessary agreement in place, they may approve certain agreements related to energy development.184 However, for a variety of reasons, few tribes have taken advantage of these provisions.185 Finally, the federal government regulates energy services within Indian country under the Federal Power Act, 186 the Public Utility Regulatory Practices Act, 187 and the Natural Gas Act.188 Under the Natural Gas Act, the Federal Energy Regulatory Commission has the sole jurisdiction to approve the siting, permitting, and operation of interstate natural gas pipelines.

In addition to these statutes specific to energy, federal environmental statutes also impact the development of energy resources within Indian country. It is therefore notable that several federal environmental statutes also apply to Indian country, as statutes of general applicability. Relevant federal environmental statutes include: the National Environmental Policy Act, 189 National Historic Preservation Act,190 Clean Water Act,191 Clean Air Act,192 and Endangered Species Act. 193

\section{E. Rights of Way}

Rights-of-way through reservations, such as railroads and state highways, are trust land. (Rightsof-way are discussed in Chapter V, section A.3.) Consequently, the Ninth Circuit upheld a Tribe's right to impose a tax on a railroad's possessory interests within the reservation. Burlington Northern Railroad Co. v. Blackfeet Tribe, 924 F.2d 899, 904 (9th Cir. 1991). Six years later, however, the Supreme Court held that, for purposes of tribal jurisdiction over state highways, rights-of-way were the equivalent of fee land:

Forming part of the State's highway, the right-of-way is open to the public, and traffic on it is subject to the State's control. The Tribes have consented to, and received payment for, the State's use of the 6.59-mile stretch for a public highway. They have retained no gatekeeping right. So long as the stretch is maintained as part of the State's highway, the Tribes cannot assert a landowner's right to occupy and exclude. We therefore align the right-of-way, for the purpose at hand, with land alienated to non-Indians.194

Based on Strate, the Ninth Circuit expressly overruled Burlington Northern. Big Horn County Electric Coop. v. Adams, 219 F.3d 944 (9th Cir. 2000). The Crow Tribe enacted a Railroad and

18325 U.S.C. $\$ 321,323$.

18425 U.S.C. $\$ \S 3504,415(\mathrm{~h})$.

185 Elizabeth Ann Kronk Warner, Tribal Renewable Energy Development Under the HEARTH Act: An

Independently Rational, but Collectively Deficient, Option, 55 ARIZ. L. REV. 1031 (2013); Elizabeth Ann Kronk, Tribal Energy Resource Agreements: The Unintended "Great Mischief for Indian Energy Development" and the Resulting Need for Reform, 29 PACE ENVTL. L. REV. 811 (2012).

18616 U.S.C. $\$ 791$ et seq. (2012).

18716 U.S.C. $\$ 2601$ et seq.

18815 U.S.C. $\$ 717$ et seq.

18942 U.S.C. $\$ 4321$ et seq.

19016 U.S.C. $\$ 470$ et seq.

19133 U.S.C. $\$ 1251$ et seq.

19242 U.S.C. $\$ 7401$ et seq.

19316 U.S.C. $\S 1531$ et seq.

194 Strate v. A-1 Contractors, 520 U.S. 438, 459 (1997). 
Utility Tax Code, assessing a three percent tax on the full fair market value of utility property located on tribal or trust lands within the Crow Reservation. The utility objected, claiming that the tribe had no authority to tax its property because the property was located on a congressionally granted right-of-way, the equivalent under Strate of fee land. The Ninth Circuit agreed that Strate governed, even though the tribe argued that the utility's rights-of-way were neither open to the public nor under the control of the state.

Applying the Montana tests for tribal authority over nonmembers on fee lands, the court held that neither exception permitted a tribal tax on utility property located on tribal trust lands. The court dismissed the first exception, even though the utility had a consensual relationship with the tribe. Under that exception, the court determined that a tribe could tax the activities of nonmembers, but not the value of property owned by nonmembers. In addition, the court determined that the second "direct effects" exception from Montana did not apply because the tax was not necessary to protect tribal self-government or control internal relations.

In Burlington Northern, the Ninth Circuit held that: "The Tribes' power to tax nonmembers derives from the Tribes' continuing property interest. Like the continuing property interest in the leases at issue in Merrion [citation omitted], this interest was not extinguished by the right-of-way grant."

\section{F. Other Future Implications of McGirt}

Great nations, like great men, should keep their word. - Federal Power Commission v. Tuscarora Indian Nation, 362 U.S. 99, 142 (Black, J., dissenting)

My ancestor ... who signed the treaty ... accepted the word of the United States - that this treaty would protect not only the Indian way of life for those then living, but also for all generations yet unborn. - Jerry Meninick, Citizen of the Yakama Nation 195

More broadly than natural resource development in Indian country, the McGirt decision possibly signals another important implication moving forward - the strength of legal claims based on tribal treaty rights. As explained above, the McGirt decision affirms the Reservation boundaries established in the treaties at issue.196 And, Justice Gorsuch affirms the importance of honoring treaties, unless explicitly abrogated by Congress, in his opinion. 197

Tribes have often turned to their treaties with the United States as a way of protecting valuable rights. For example, the Swinomish Indian Tribal Community successfully asserted its treaty rights to fish, a cultural "keystone" for the Tribe, in the 1970s.198 Historically, federal courts have interpreted treaties in expansive and progressive ways given the time of such decisions. For example, in 1908, the United States Supreme Court determined that tribal treaties, which made no explicit mention, of water rights reserved water rights sufficient for the primary purposes of a

195 Mary Christina Wood, The Indian Trust Responsibility: Protecting Tribal Lands and Resources Through Claims of Injunctive Relief Against Federal Agencies, 39 Tulsa L. Rev. 355, 356 (2003) (citation omitted).

196 [INSERT SUPRA NOTE]

197 [INSERT]

198 Swinomish Indian Tribal Community, Swinomish Climate Change Initiative Climate AdAPTATION ACTION PLAN 10 (October 2010), available at: http://www.swinomish.org/climate_change/Docs/SITC_CC_AdaptationActionPlan_complete.pdf. 
reservation.199 Similarly, in 1974, the Western District of Washington district court determined that tribal treaties provided for a reserved right of tribes to be co-managers of fisheries along with the states, despite the fact that the treaties involved did not explicitly reference such a right to co-management.200 While these decisions are well-established and respected today, they were groundbreaking and novel in their time. These decisions and others demonstrate the capacity for federal courts to interpret treaties in broad ways in order to protect tribal resources. Moreover, such decisions also demonstrate federal courts' willingness to demand specific action from the federal government on the basis of implicit treaty provisions.

Recent U.S. Supreme Court decisions support this historical trend of upholding treaty provisions. Notably, since Justice Gorsuch joined the Court in 2017, the Court has upheld tribal treaty rights in three cases (the third being the McGirt decision). Prior to the Court's decision in McGirt, the Court upheld tribal treaty rights in three recent cases (since Justice Gorsuch joined the Court): Washington v. United States, Washington State Department of Licensing v. Cougar Den, Inc., and Herrara v. Wyoming.

In Washington v. United States, the U.S. Supreme Court issued a single sentence opinion stating that "[t]he judgment is affirmed by an equally divided Court." 201 At issue in this case was the interpretation of treaties entered into between tribes and the federal government in the 19th Century. In 1854 and 1855, Indian tribes in the Pacific Northwest entered into a series of treaties, now known as the "Stevens Treaties," negotiated by Isaac I. Stevens, Superintendent of Indian Affairs and Governor of Washington Territory. Under the Stevens Treaties ("Treaties") at issue in this case, the tribes relinquished large swaths of land. In exchange for their land, the tribes were guaranteed a right to off-reservation fishing.

The Tribes contend that Washington State had violated, and was continuing to violate, the Treaties by building and maintaining culverts that prevented mature salmon from returning from the sea to their spawning grounds; prevented smolt (juvenile salmon) from moving downstream and out to sea; and prevented very young salmon from moving freely to seek food and escape predators. In 2007, the district court held that in building and maintaining these culverts Washington had caused the size of salmon runs in the Case Area to diminish and that Washington thereby violated its obligation under the Treaties. In 2013, the court issued an injunction ordering Washington to correct its offending culverts. The Ninth Circuit affirmed.

The equally divided Court affirmed the U.S. Court of Appeals for the Ninth Circuit's decision finding that culverts infringed on the Tribes' treaty right to take fish at usual and accustomed places. Further, the State of Washington also appealed the lower court's decision dismissing Washington's equitable claims that the federal government told the State to design culverts a certain way and then brought suit challenging the culverts. Finally, the State of Washington had also appealed to challenge the issuance of an injunction that allegedly violated federalism and comity principles. Given the equally divided Court, the State of Washington's arguments on these two points failed.

199 Winters v. United States, 207 U.S. 564.

200 United States v. Washington, 384 F. Supp. 312 (W.D. Wash. 1974).

201138 S.Ct. 1832 (2018). 
In Washington State Department of Licensing v. Cougar Den, Inc., Cougar Den, Inc. - a wholesale fuel importer, owned by a citizen of the Yakama Nation and incorporated under Yakama law, challenged the application of taxes by the Washington State Department of Licensing. The State of Washington assessed Cougar Den a total of \$3.6 million in taxes, penalties, and licensing fees for failure to pay taxes on fuel it imported into the State of Washington on its way for sale on the Yakama Nation. The Court ultimately determined that application of the State's taxes and fees was not appropriate given the Yakama Nation's treaty right to travel upon all public highways in common with citizens of the United States.

Cougar Den is a wholesale fuel importer owned by a member of the Yakama Nation. Cougar Den imports fuel from Oregon over Washington's public highways to the Yakama Reservation. The Washington State Department assessed Cougar Den \$3.6 million in taxes and fees for importing the fuel into Washington. Cougar Dean appealed stating that the tax was pre-empted by an 1855 treaty which reserved the "right, in common with citizens of the US to travel upon all public highways." The Washington Supreme Court held the tax was pre-empted by the treaty.

In an opinion authored by Justice Breyer, and joined by Justices Sotomayor and Kagan, the Court determined that the 1855 treaty between the Yakama Nation and the federal government pre-empted that application of the State of Washington's fuel tax to Cougar Den. In reaching this decision, the Court explained that it had previously interpreted language similar to the one at issue in this treaty, and, in every instance, "has stressed that the language of the treaty should be understood as bearing the meaning that the Yakamas understood it to have." Further, the Court explained that treaty terms should be read in the terms that the Tribe would have understood them, that the right to travel included the right to travel with goods for sale, and that taxes would burden this right to travel.

Justice Gorsuch wrote a concurring opinion, in which Justice Ginsburg joined. In agreeing that the taxes did not apply, Justice Gorsuch explained that, when interpreting a treaty, the treaty should be interpreted as the tribe would have understood it at the time. Here, there was evidence in the record to support that the Yakama Nation would have understood the treaty provision as the right to travel far distances for the purpose of trade. The State of Washington argued that the provision meant that the Nation could use highways the same as other citizens of the State, but Justice Gorsuch explained that "the consideration the Yakamas supplied - millions of acres desperately wanted by the United States to settle the Washington territory - was worth far more than an abject promise they would not be made prisoners on their reservation." Id. at *2. Finally, in a paragraph that has already been readily quoted by those working in Indian country, Justice Gorsuch explained:

Really, this case just tells an old and familiar story. The State of Washington includes millions of acres that the Yakamas ceded to the United States under significant pressure. In return, the government supplied a handful of modest promises. The state is now dissatisfied with the consequences of one of those promises. It is a new day, and now it wants more. But today and to its credit, the Court holds the parties to the terms of their deal. It is the least we can do. 
In Herrera v. Wyoming,202 a Crow tribal member appealed his state law conviction for hunting in Wyoming's Bighorn National Forest. As Justice Sotomayor, writing for the five justice majority, explained:

The case [Race Horse] established that the crucial inquiry for treaty termination analysis is whether Congress has expressly abrogated an Indian treaty right or whether a termination point identified in the treaty itself has been satisfied. Statehood is irrelevant to this analysis unless a statehood Act otherwise demonstrates Congress' clear intent to abrogate a treaty, or statehood appears as a termination point in the treaty....

Accordingly, the majority wrote, "[Herrera $]$ is not a hard case," and the rights reserved by the Crow Tribe in the 1868 Treaty were not abrogated by Wyoming's statehood.203 The Court in Herrera therefore rejected arguments similar to those made in McGirt - that the admission of a state to the Union somehow abrogated a tribe's treaty rights.

Given tribes relatively "low" success rate in front of the U.S. Supreme Court,204 it is remarkable that claims based on tribal treaties have been successful in all four of the recent cases decided by the U.S. Supreme Court. And, in all of these cases, Justice Gorsuch has been in the majority. These two trends suggest that claims based on tribal treaty rights continue to be relatively strong claims in the federal courts, and it also suggests Justice Gorsuch may be sympathetic to these types of claims. In terms of future implications, it is therefore likely that individual Indians and tribal parties will likely attempt to avail themselves of claims based on treaty rights, and this will likely be true in the natural resource development realm as well as other types of claims.

\section{Conclusion}

Tribes have significant natural resources at their disposal. The McGirt decision has the potential to further promote Tribes as a key player in energy development in the United States. While there is always the possibility that courts will interpret the McGirt decision to only apply to the Major Crimes Act and criminal jurisdiction, Justice Gorsuch never explicitly limits the decision in this way. Moreover, the definition of "Indian Country" in Indian criminal law has historically been used in numerous other contexts, including civil regulatory areas. In Atkinson Trading Company, however, the Court found the Ninth Circuit's reliance on that statute "misplaced," noting that $\S$ 1151 is "a statute conferring upon Indian tribes jurisdiction over certain criminal acts." The Court explained:

Although $\S 1151$ has been relied upon to demarcate state, federal, and tribal jurisdiction over criminal and civil matters, we do not here deal with a claim of statutorily conferred power. Section 1151 simply does not address an Indian tribe's inherent or retained sovereignty over nonmembers on non-Indian fee land.205

202139 S.Ct. 1686 (2019),

$203 \mathrm{Id}$. at 1700.

204 David H. Getches, Beyond Indian Law: The Rehnquist Court's Pursuit of States' Rights, Color-Blind Justice and Mainstream Values, 86 MinN. L. REV. 267 (2001), available at https://scholar.law.colorado.edu/articles/580. 205532 U.S. 645 (2001). 
Further, in his opinion, Justice Gorsuch tees up some legal arguments, such as procedural bars, res judicata, statutes of repose, and laches, as potential arguments to be used to curb a widespread upending of federal Indian law as a result of the McGirt decision.206 Federal courts may end up accepting such arguments as limits on the Court's decision. Ultimately, the full implications of McGirt will take time to be revealed, but Tribes and their interests will not easily be overlooked. "Far from being relics of a bygone era, Indian tribal powers bear the fine burnish of everyday use."207 "But it is unclear why pessimism should rule the day." 